\title{
MINERALOGY OF SOILS FROM DIFFERENT AGROECOLOGICAL REGIONS OF BANGLADESH : REGION 29-NORTHERN AND EASTERN HILLS
}

\section{Sarker, Md. Mosharaf Hossain}

Laboratory of Soil Science, Division of Bioproduction Environmental Sciences, Department of Agro-environmental Sciences, Faculty of Agriculture, Kyushu University | Department of Soil Science, Sylhet Agricultural University

\section{Alam, Md. Jahangi $r$}

Laboratory of Soil Science, Division of Bioproduction Environmental Sciences, Department of Agro-environmental Sciences, Faculty of Agriculture, Kyushu University | Department of Soil Science, Bangladesh Agricultural University

\section{Moslehuddin, Abu Zofar Md.}

Laboratory of Soil Science, Division of Bioproduction Environmental Sciences, Department of Agro-environmental Sciences, Faculty of Agriculture, Kyushu University I Department of Soil Science, Bangladesh Agricultural University

Hoque, Tahsina Sharmin

Laboratory of Soil Science, Division of Bioproduction Environmental Sciences, Department of Agro-environmental Sciences, Faculty of Agriculture, Kyushu University | Department of Soil Science, Bangladesh Agricultural University

他

https://doi.org/10.5109/1801780

出版情報：九州大学大学院農学研究院紀要. 62 (1)，pp. 183-187，2017-02-24. Faculty of Agriculture, Kyushu University

バージョン：

権利関係 : 


\title{
MINERALOGY OF SOILS FROM DIFFERENT AGROECOLOGICAL REGIONS OF BANGLADESH: REGION 29- NORTHERN AND EASTERN HILLS
}

\section{Md. Mosharaf Hossain SARKER ${ }^{1}$, Md. Jahangir ALAM ${ }^{2}$, Abu Zofar Md. MOSLEHUDDIN ${ }^{2}$, Tahsina Sharmin HOQUE ${ }^{2}$ and Yuki MORI*}

\author{
Laboratory of Soil Science, Division of Bioproduction Environmental Sciences, \\ Department of Agro-environmental Sciences, Faculty of Agriculture, \\ Kyushu University, Fukuoka 812-8581 \\ (Received October 28, 2016 and accepted November 4, 2016)
}

\begin{abstract}
Bangladesh has been divided into 30 Agro-ecological Regions (AEZs) based on which applied agricultural research has currently been conducted. Due to the unavailability of sufficient mineralogical information of soils of those AEZs, there was an initiative to study mineralogical composition of major soils of different AEZs of the country. One of the parts of such attempt, the mineralogy of eight soils from five soil series (Pritimpasha, Varella, Pahartali, Mirsarai and Borkal) from AEZ 29, Northern and Eastern Hills, has been reported in this manuscript. The soils of the AEZ were medium textured, non-saline and slightly acidic to strongly acidic in nature. The average content of $<2 \mu \mathrm{m}$ clay fraction was $17.9 \%$ and it varied from 7.9 to $32.5 \%$. The $2-20 \mu \mathrm{m}$ silt fraction lied between 14.1 to $28.7 \%$ with an average of $21.5 \%$. The clay fraction was dominated with mica, chlorite, kaolinite, quartz in all the soils studied. Presence of two interstratified minerals namely, vermiculite-chlorite intergrade and interstratified mica-chlorite minerals were evident in some samples. The findings of the present study do not support the proposed mineralogical suits of micakaolinite-vermiculite and kaolinite-mica for this AEZ.
\end{abstract}

Key words: Clay mineralogy, Northern and Eastern Hills, Bangladesh

\section{INTRODUCTION}

Bangladesh with an area of 147570 sq. $\mathrm{km}$ is a land of agriculture. The contribution of agriculture to GDP of the country is in a decreasing trend in the recent past. In spite of that agriculture has major role in country's economy (BBS, 2013). The 77\% country's total people are living in rural areas which primarily depend on a poorly developed agriculture for food (AIS, 2015). Soil is the precious natural resource for global sustenance being the source of food, fiber and fuel. Soil is one of the main factors of sustainable development which is important for proper functioning of ecosystem and assurance of food security. Judicial soil management is the art of taking care of soil with full potential for further cultivation. Soil is one of the key natural resources of Bangladesh, but due to increase of cropping intensity deficiency of nutrients has been appeared in soil which has a common concern throughout the country. Moreover, our soil health has been threatened by climate change, overexploitation of resources, land degradation, water stress and deforestation.

Physiographically, the land of Bangladesh is mainly classified into Holocene floodplains (80\%), Tertiary hills $(12 \%)$ and Pleistocene terrace (8\%). Based on mode of information and morphological appearance, soils of Bangladesh are grouped into 21 general soil types accord-

\footnotetext{
1 Department of Soil Science, Sylhet Agricultural University, Sylhet 3100, Bangladesh

2 Department of Soil Science, Bangladesh Agricultural University, Mymensingh 2202, Bangladesh

* Corresponding author (E-mail: y-mori@agr.kyushu-u.ac.jp)
}

ing to the Bangladesh soil classification system that can be correlated with the USDA taxonomy and FAOUNESCO system of soil classification (Saheed, 1984). On the basis of land form, geology and agro-climatic condition, Bangladesh has been divided into 30 agro-ecological regions (popularly known as AEZs), 88 sub-regions of 535 agro-ecological units (FAO-UNDP, 1988); refer to the previous paper (Islam et al., 2003) for the map of AEZs.

The present shred of work deals with the mineralogy of soils from the AEZ 29 (Northern and Eastern Hills). The AEZ 29 covered 1817172 ha area which is situated in Rangamati (456500 ha), Bandarban (442300 ha), Khagrachhari (316700 ha), Chittagong (232800 ha), Cox's Bazar (133500 ha), Moulvibazar (1292 ha), Habiganj (49500 ha), Sylhet (27000 ha), Comilla (10800 ha), Sherpur (8200 ha) and Feni (6000 ha) districts of Bangladesh (BARC, 2012). Irregular undulated hilly area comprises the region. Very steep slopes and few hillocks with flat summit are the general view of those areas.

Yellow-brown to deep brown colored permeable loamy soils composed of most hilly areas. Those soils have low moisture holding capacity with mainly very strongly acidic soil reaction. Sand, silt and clay content of underlying bed rock, mainly sedimentary rocks, and extent of erosion occurred on it are variable. As a result, there is a complex soil patterns prevailing in those areas. The predominant general soil types of those areas are Brown Hill Soils (BARC, 2012).

Degree of weathering is indicated by the soil mineral content of an area. The presence or absence of specific mineral in soil gives idea about soil forming process (Schulze, 1989). Most of the mineralogical studies in 
Bangladesh have been done for the agriculturally important soil series representing some specific physiographic units or agro-ecological region. All available information on clay mineralogy of Bangladesh was summarized by Moslehuddin et al. (1999) and a tentative clay mineralogical map of Bangladesh was proposed. In such situation, due to the lack of sufficient information about this issue, an attempt has been undertaken to study the mineralogy of soils from all AEZs of Bangladesh in the Department of Soil Science, Bangladesh Agricultural University (BAU), Mymensingh. Moslehuddin et al. (1999) placed the AEZ 29 under mica-kaolinite-vermiculite* suite (eastern part) and kaolinite-mica suite (northern part). Here asterisk mark denoted partial chloritization of some vermiculite. Further study is indispensable to confirm the comprehensiveness of this. In this context, the present study was undertaken to determine the mineralogical composition of soils collected from AEZ 29 and to validate the proposed mineralogical suit of the AEZ.

\section{MATERIALS AND METHODS}

\section{Soil used}

Eight soil samples of AEZ 29 Northern and Eastern Hills were collected from $0-15 \mathrm{~cm}$ soil depth. The soils pertained to five soil series namely, Pritimpasha (2 samples), Varella (3 samples), Pahartali (1 sample), Mirsarai (1 sample) and Borkal (1 sample). The first two series were located in the Burichong upazila of Comilla district while the other three were located in the Teknaf upazila of Cox's Bazar district. General features of these soils are presented in Table 1 . The soil samples were dried at room temperature, crushed, mixed thoroughly, sieved with $2-\mathrm{mm}$ sieve using standard procedures and preserved in plastic containers for subsequent different laboratory analyses.

\section{Particle-size analysis}

After treating the processed soil samples with hot 7\% $\mathrm{H}_{2} \mathrm{O}_{2}$ to decompose organic matter present in those sam- ples, the particles were dispersed by mechanical stirring and adjusted to the $\mathrm{pH} 10$ using $1 \mathrm{M} \mathrm{NaOH}$. By repeated stirring-sedimentation-siphoning the $<2 \mu \mathrm{m}$ fraction was separated. The $2-20 \mu \mathrm{m}$ fractions were separated with repeated sedimentation-siphoning whereas the 20-53, 53-212, 212-2000 $\mu \mathrm{m}$ fractions were separated by wet sieving. In order to calculate particle-size distribution the weight of each fraction was measured.

\section{Determination of $\mathrm{pH}$ and EC}

The soil pH was measured electrochemically using a glass-electrode $\mathrm{pH}$ meter in the soil suspension having a soil:water ratio of 1:2.5 after 30 minutes shaking. The electrical conductivity (EC) was determined by an EC meter in the soil suspension having a soil:water ratio of 1:5 after 30 minutes shaking.

\section{Determination of exchangeable cations ( $\mathrm{Na}, \mathrm{K}, \mathrm{Ca}$ )}

Exchangeable $\mathrm{K}, \mathrm{Ca}$ and $\mathrm{Na}$ were extracted by adding $8 \mathrm{~mL}$ of $\mathrm{CH}_{3} \mathrm{CHOONH}_{4}$ into a $15 \mathrm{~mL}$ centrifugal tube having $2.5 \mathrm{~g}$ soil sample in it. After 10 minutes shaking of the tube, the suspension was centrifuged for 5 minutes at $1500 \mathrm{rpm}$ and the supernatant was decanted and filtered into a $25 \mathrm{~mL}$ volumetric flask. The process was repeated two more times. The concentration of extracted $\mathrm{K}, \mathrm{Na}$ and $\mathrm{Ca}$ were determined directly by flame photometer.

\section{Mineralogical analysis}

Duplicate clay sols containing $50 \mathrm{mg}$ of clay $(<2 \mu \mathrm{m})$ were taken to prepare the specimens for X-ray diffraction (XRD). The sols were placed in $10 \mathrm{~mL}$ centrifugal tubes. Washing through centrifugation and decantation were carried out twice with $8 \mathrm{~mL}$ of an equal mixture of $1 \mathrm{M} \mathrm{NaCl}$ and $1 \mathrm{M} \mathrm{CH}_{3} \mathrm{COONa}$ ( $\mathrm{pH} 5$ ) in order to decrease the $\mathrm{pH}$ of preserved clay sols. Of the duplicate sets, one was saturated with $\mathrm{K}$ and the other with $\mathrm{Mg}$ by washing three times with $8 \mathrm{~mL}$ of $1 \mathrm{M} \mathrm{KCl}$ and $0.5 \mathrm{M} \mathrm{MgCl}_{2}$, respectively. Excess salt was removed by washing once with $8 \mathrm{~mL}$ of water.

Clay in the tube was suspended thoroughly with $1 \mathrm{~mL}$

Table 1. General information of soil samples

\begin{tabular}{lllll}
\hline Sample name & Location & Land Type $^{2)}$ & USDA $^{3)}$ soil taxonomy & Cropping pattern $^{4)}$ \\
\hline Pritimpasha-1 & Burichong Upazila ${ }^{1}$, Comilla & MHL & Aeric Haplaquepts & B- F- T.A \\
Pritimpasha-2 & Burichong Upazila, Comilla & MHL & Aeric Haplaquepts & B- A- T.A \\
Varella-1 & Burichong Upazila, Comilla & MHL & Typic Haplaquepts & B- A- T.A \\
Varella-2 & Burichong Upazila, Comilla & MHL & Typic Haplaquepts & B- F- T.A \\
Varella-3 & Burichong Upazila, Comilla & MHL & Typic Haplaquepts & B- F- T.A \\
Pahartali & Teknaf Upazila, Cox's Bazar & HL & Typic Ustipsamments & F- F- F \\
Mirsarai & Teknaf Upazila, Cox's Bazar & HL & Typic Ustipsamments & F- F- F \\
Borkal & Teknaf Upazila, Cox's Bazar & HL & Typic Ustipsamments & F- F- F \\
\hline
\end{tabular}

\footnotetext{
1) Upazila= Subdistrict;

${ }^{2)}$ HL-High Land, above flood level; MHL-Medium High Land, normally flooded up to a depth of $90 \mathrm{~cm}$ during the monsoon season.

${ }^{3)}$ USDA: United States Department of Agriculture

4) A: Aus; B: Boro; F: Fallow; T.A: Transplant Aman
} 
of water. An aliquot of $0.4 \mathrm{~mL}$ of the sol was dropped onto a glass slide $(7.6 \mathrm{~cm} \times 2.6 \mathrm{~cm})$, covering two-thirds of its area, air-dried and X-rayed (Parallel powder mount). The XRD patterns were obtained using a Rigaku $\mathrm{X}$-ray diffractometer (RINT $2100 \mathrm{~V}$ ) with $\mathrm{Cu} \mathrm{K} \alpha$ radiation at $40 \mathrm{kV}$ and $20 \mathrm{~mA}$, and at a scanning speed of $2^{\circ} 2 \theta$ $\mathrm{min}^{-1}$ over a range of 3 to $30^{\circ} 2 \theta$. In addition to the airdried specimen, the Mg-saturated clay was X-rayed after solvation with glycerol, and the $\mathrm{K}$-saturated clay was Xrayed after heating at $300^{\circ} \mathrm{C}$ and $550^{\circ} \mathrm{C}$ for $2 \mathrm{hrs}$.

\section{RESULTS}

\section{Particle-size distribution}

Based on the USDA system, particle-size distribution and textural classes of the soils were determined and have been presented in Table 2 . The average clay content of soils was $17.9 \%$ where the highest content was found in Varella-2 soil (32.5\%) and the lowest content (7.9\%) was in Pritimpasha-1 and Mirsarai soil. The clay content varied in Pritimpasha soil series from 7.9\% (Pritimpasha-1) to $18.4 \%$ (Pritimpasha-2) and in Varella soil series from $10.4 \%$ (Varella-1) to $32.5 \%$ (Varella-2). Besides, the clay contents of Pahartali, Mirsarai and Borkal soil series were 12.9, 7.9 and $25.5 \%$, respectively.

The silt fraction having the size of average $2-20 \mu \mathrm{m}$ was $21.5 \%$ and it varied from $14.1 \%$ in Pritimpasha-1 soil to $28.7 \%$ in Pritimpasha-2 soil. The $20-53 \mu \mathrm{m}$ fraction varied from 19.2\% in Pritimpasha-2 and Borkal soil to $37.7 \%$ in Varella-3 soil. The sand fraction with average size of $53-212 \mu \mathrm{m}$ was $29.4 \%$ and it ranged from $5.7 \%$ in Varella-3 soil to $45.8 \%$ in Mirsarai soil. Except Varella-2 and Varella-3, this sand fraction was above $10 \%$ in all other soils. The coarse sand of $212-2,000 \mu \mathrm{m}$ was found in a low range (from $0.2 \%$ in Varella-3 to $7.9 \%$ in Borkal soil). According to the USDA system for textural classes in AEZ 29, five samples were loam, two were silt loam and one was silty clay loam out of eight soil samples.

\section{Soil pH and EC}

Strongly acidic to slightly acidic soil reaction was found in the soils of Northern and Eastern Hills with the $\mathrm{pH}$ values ranging between 4.85 (Varella-3) and 6.04 (Pritimpasha-2) (Table 3). The EC value varied from 0.02 (Pritimpasha-2) to 0.08 (Varella-3) dS m ${ }^{-1}$ (Table 3).

\section{Exchangeable sodium, potassium and calcium}

The exchangeable sodium ranged from $0.06 \mathrm{cmolc}$ $\mathrm{kg}^{-1}$ (in Mirsarai series) to 0.46 cmolc $\mathrm{kg}^{-1}$ (in Pritimpasha-1 and Pritimpasha-2 soil series) with an

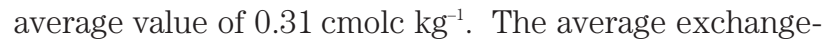

Table 2. Particle-size distribution and textural classes of soil samples

\begin{tabular}{|c|c|c|c|c|c|c|}
\hline \multirow{2}{*}{ Sample name } & \multicolumn{5}{|c|}{ Particle-size distribution (\%) } & \multirow{2}{*}{$\begin{array}{l}\text { USDA soil } \\
\text { textural class }\end{array}$} \\
\hline & $<2 \mu \mathrm{m}$ & $2-20 \mu \mathrm{m}$ & $20-53 \mu \mathrm{m}$ & $53-212 \mu \mathrm{m}$ & $212-2000 \mu \mathrm{m}$ & \\
\hline Pritimpasha-1 & 7.9 & 14.1 & 25.8 & 45.5 & 6.7 & Loam \\
\hline Pritimpasha-2 & 18.4 & 28.7 & 19.2 & 33.2 & 0.5 & Loam \\
\hline Varella-1 & 10.4 & 17.4 & 21.5 & 45.5 & 5.2 & Loam \\
\hline Varella-2 & 32.5 & 19.3 & 34.5 & 9.9 & 3.8 & Silty clay loam \\
\hline Varella-3 & 28.0 & 28.4 & 37.7 & 5.7 & 0.2 & Silt loam \\
\hline Pahartali & 12.9 & 27.9 & 35.4 & 19.4 & 4.4 & Silt loam \\
\hline Mirsarai & 7.9 & 19.4 & 26.3 & 45.8 & 0.6 & Loam \\
\hline Borkal & 25.5 & 16.9 & 19.2 & 30.5 & 7.9 & Loam \\
\hline Average & 17.9 & 21.5 & 27.5 & 29.4 & 3.6 & \\
\hline
\end{tabular}

Table 3. pH, EC, exchangeable $\mathrm{Na}, \mathrm{K}$ and $\mathrm{Ca}$ of soil samples

\begin{tabular}{|c|c|c|c|c|c|}
\hline Sample name & $\mathrm{pH}$ & $\begin{array}{c}\mathrm{EC} \\
\left(\mathrm{dS} \mathrm{m} \mathrm{m}^{-1}\right)\end{array}$ & $\begin{array}{l}\text { Exchangeable } \mathrm{Na} \\
\quad\left(\mathrm{cmol}_{\mathrm{c}} \mathrm{kg}^{-1}\right)\end{array}$ & $\begin{array}{l}\text { Exchangeable } \\
\mathrm{K}\left(\mathrm{cmol}_{\mathrm{c}} \mathrm{kg}^{-1}\right)\end{array}$ & $\begin{array}{l}\text { Exchangeable } \\
\mathrm{Ca}\left(\mathrm{cmol}_{\mathrm{c}} \mathrm{kg}^{-1}\right)\end{array}$ \\
\hline Pritimpasha-1 & 5.02 & 0.07 & 0.46 & 0.16 & 3.70 \\
\hline Pritimpasha-2 & 6.04 & 0.02 & 0.46 & 0.14 & 2.87 \\
\hline Varella-1 & 5.20 & 0.08 & 0.42 & 0.14 & 4.93 \\
\hline Varella-2 & 5.52 & 0.06 & 0.27 & 0.16 & 5.54 \\
\hline Varella-3 & 4.85 & 0.08 & 0.29 & 0.30 & 4.70 \\
\hline Pahartali & 5.39 & 0.06 & 0.24 & 0.70 & 0.78 \\
\hline Mirsarai & 5.55 & 0.05 & 0.06 & 0.40 & 3.70 \\
\hline Borkal & - & - & - & - & - \\
\hline Average & 5.37 & 0.13 & 0.31 & 0.29 & 3.75 \\
\hline
\end{tabular}


able $\mathrm{K}$ content was $0.29 \mathrm{cmolc} \mathrm{kg}^{-1}$ having a range from $0.14 \mathrm{cmolc} \mathrm{kg}^{-1}$ (in Pritimpasha-2 and Varella-1 series) to 0.70 cmolc $\mathrm{kg}^{-1}$ (in Pahartali series). The exchangeable Ca content varied from $0.78 \mathrm{cmolc} \mathrm{kg}^{-1}$ (in Pahartali series) to $5.54 \mathrm{cmolc} \mathrm{kg}^{-1}$ (in Varella-2) (Table 3) having

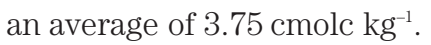

\section{Mineralogical composition of clay fraction}

The clay $(<2 \mu \mathrm{m})$ fraction of dominating samples in XRD patterns are shown in figures 1 and 2 . The peaks of the most samples are sharp, indicating the good crystallinity and/or large crystallite size of the minerals. Various relevant measurements as well as ratios of the peaks were used to detect the existence of mineral components of the soil samples under study i.e., mica, chlorite, kaolinite, smectite, vermiculite, quartz and feldspars as described by Akter et al. (2015).

According to Moslehuddin and Egashira (1996), the approximate mineral composition of the clay fraction $(<2 \mu \mathrm{m})$ was estimated based on the relative peak intensities of the respective minerals in the XRD charts following was presented in Table 4. Among the minerals identified, mica was found as the most dominant one and it
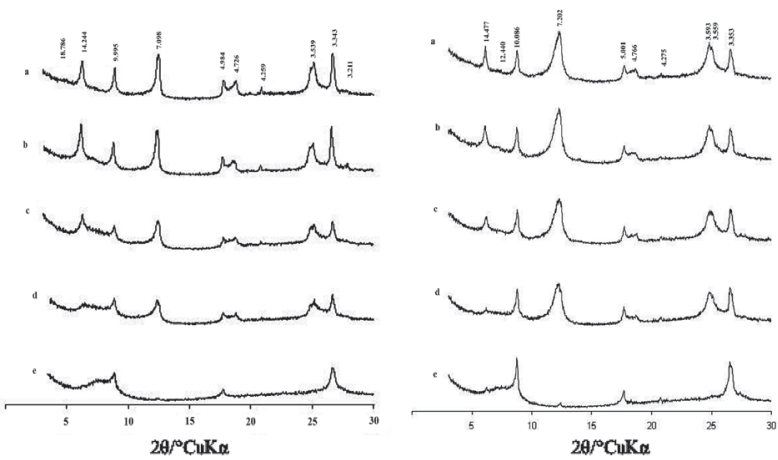

Fig. 1. X-ray diffraction patterns of the $<2 \mu \mathrm{m}$ clay fraction of Pritimpasha-1 (left) and Varella-2 (right) soil. Spacing is in $\AA$. Treatments: a) Mg-saturation and glycerol-solvation; b) Mg-saturation and air-drying; c) K-saturation and airdrying; d) $\mathrm{K}$-saturation and heating at $300^{\circ} \mathrm{C}$; e) $\mathrm{K}$-saturation and heating at $550^{\circ} \mathrm{C}$. varied from 22\% in Varella-2 soil to 46\% in Pahartali soil. Following mica, chlorite was present in considerable amount compared to other minerals ranging from 14 to 26\%. Pritimpasha-1 and Varella-3 soils possess the highest amount of chlorite while the lowest amount was found in Pahartali soil. Kaolinite was also found in all the soil samples having a range from 9 to $41 \%$ with the highest value in Varella-2 soil and the lowest value in Pahartali soil. Smectite was found in little amount in Mirsarai (13\%) soil and in negligible amount in Pahartali (5\%) soil. Vermiculite was identified in two samples namely Varella-2 (6\%) and Pahartali (9\%) soils. Quartz was found in all the soil samples ranging from 5\% (Varella-2) to $18 \%$ (Varella-1). A little amount of feldspar was identified in all the soils varying from 2\% (Pritimpasha-1, Pritimpasha-2, Varella-2, Pahartali and Mirsarai) to 5\% (Varella-1). In two soil samples (Pritimpasha-2 and Varella-1), goethite was present in a negligible amount varied from 1 to $2 \%$. Besides, lepidocrocite was only identified in Pritimpasha-2 soil (8\%). Two soil samples had vermiculite-chlorite intergrade mineral viz. Varella-1 $(12 \%)$ and Borkal (14\%). Mica-chlorite interstratified mineral was found in one sample viz. Borkal (5\%) soil.
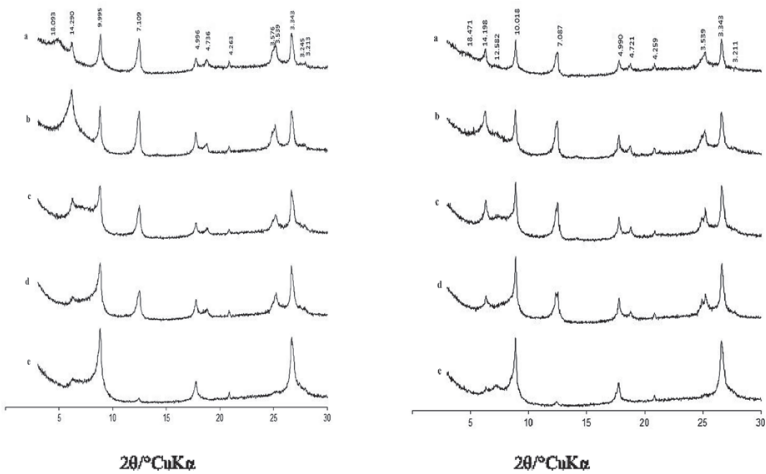

Fig. 2. X-ray diffraction patterns of the $<2 \mu \mathrm{m}$ clay fraction of Mirsarai (left) and Borkal (right) soil. Spacing is in $\AA$. Treatments: a) Mg-saturation and glycerol-solvation; b) Mg-saturation and air-drying; c) K-saturation and airdrying; d) $\mathrm{K}$-saturation and heating at $300^{\circ} \mathrm{C}$; e) $\mathrm{K}$-saturation and heating at $550^{\circ} \mathrm{C}$.

Table 4. Approximate mineral contents (\%) in the clay fraction $(<2 \mu \mathrm{m})$ of soil samples of AEZ 29

\begin{tabular}{|c|c|c|c|c|c|c|c|c|c|c|c|}
\hline \multirow{2}{*}{ Sample name } & \multicolumn{11}{|c|}{ Minerals } \\
\hline & $\mathrm{Mc}$ & $\mathrm{St}$ & $\mathrm{Vt}$ & $\mathrm{Ch}$ & $\mathrm{Kt}$ & $\mathrm{Vt}-\mathrm{Ch}$ & $\mathrm{Mc} / \mathrm{Ch}$ & $\mathrm{Qr}$ & $\mathrm{Gt}$ & $\mathrm{Lp}$ & $\mathrm{Fd}$ \\
\hline Pritimpasha-1 & 36 & - & - & 26 & 22 & - & - & 14 & - & - & 2 \\
\hline Pritimpasha-2 & 37 & - & - & 17 & 17 & - & - & 17 & 2 & 8 & 2 \\
\hline Varella-1 & 35 & - & - & 16 & 13 & 12 & - & 18 & 1 & - & 5 \\
\hline Varella-2 & 22 & - & 6 & 24 & 41 & - & - & 5 & - & - & 2 \\
\hline Varella-3 & 28 & - & - & 26 & 25 & - & - & 17 & - & - & 4 \\
\hline Pahartali & 46 & 5 & 9 & 14 & 9 & - & - & 15 & - & - & 2 \\
\hline Mirsarai & 40 & 13 & - & 18 & 12 & - & - & 15 & - & - & 2 \\
\hline Borkal & 38 & - & - & 16 & 11 & 14 & 5 & 13 & - & - & 3 \\
\hline
\end{tabular}

Abbreviations: Mc: mica; St: smectite; Vt: vermiculite; Ch: chlorite; Kt: kaolinite; Vt-Ch: vermiculite-chlorite intergrade; Mc/Ch: interstratified mica/chlorite; Qr: quartz; Gt: goethite; Lp= lepidocrocite; Fd: feldspar. 


\section{DISCUSSION}

According to particle-size distribution it is evident that most of the soils from AEZ 29 were medium textured with loam to silt loam textural classes while the exception was in Varella-2 soil which possess silty clay loam texture. According to the reports of SRDI (1999 \& 2001), in context of textural classes the soils of Pritimpasha and Varella series were grouped as clay loam and the soils of Pahartali as loam or sandy loam which partially supports the present data. Strongly acidic to slightly acidic nature of soils under this study is in agreement with BARC (2012). The results are accorded to the report of SRDI (1999) and SRDI (2001) regarding the soil reaction of relevant soil series. Again, the results of the present study indicate that all the soils were nonsaline in nature which is well fitted with BARC (2012). The exchangeable $\mathrm{K}$ content was very high in one soil, high in one soil, optimum in one soil and low in four soils. On the other hand, the exchangeable Ca content was very low in one soil, low in one soil, medium in three soils and optimum in one soil. SRDI $(1999,2000)$ also support the present data in relation to exchangeable $\mathrm{K}$ and Ca content of the soils.

Mica, chlorite and kaolinite were the three major minerals with negligible amount of smectite and vermiculite as indicated by the results of the present study. Micachlorite and vermiculite-chlorite intergrade minerals were almost unavailable except Varella-1 and Borkal soil. Moslehuddin et al. (1999) put the soils of Northern and Eastern Hills (eastern part) in the mica-kaolinite-vermiculite* suite where mica, kaolinite and vermiculite are the major minerals and parts of vermiculite being chloritized which does not support the present data. Again, they also placed the soils of Northern and Eastern Hills (northern part) in the kaolinite-mica* suite where kaolinite is the predominant mineral which partially supports the present data. However, the AEZ 29 has coverage of large hilly areas of Bangladesh and the present study area was limited to only a part of this AEZ. Therefore, intensive study is recommended with soils from other areas of this AEZ for final comment on it.

\section{CONCLUSION}

Mostly non-saline, medium textured with strongly acidic to slightly acidic nature of the soil samples were observed in Northern and Eastern Hills region. Mica, chlorite and kaolinite are the dominant minerals in clay fraction. Hence, the results of the present study do not confirm the mica-kaolinite-vermiculite* suite but partially confirm kaolinite-mica suite for this AEZ by Moslehuddin et al. (1999). Further study is necessary to confirm this issue. The findings of this research are useful for solving the soil related problems and for consideration of land use and management, especially in terms of nutrient and water management as well as crop selection for the area.

\section{ACKNOWLEDGEMENTS}

We are very grateful to the staffs of Soil Resource Development Institute (SRDI) for helping in collection of the soil samples from Comilla district. The three soil samples of Teknaf upazila were collected during field activities of the research project entitled "The Political Ecology of the Poverty and Deforestation in Teknaf Peninsula" [Scientific grant-in-aid (grant number 24401040) from Japanese Ministry of Education and Technology] through Faculty of Design, Kyushu University, Japan.

\section{REFERENCES}

Akter, F., A. Z. M. Moslehuddin, M. A. Kader, M. M. H. Sarker and Y. Mori 2015 Mineralogy of Soils from Different Agroecological Regions of Bangladesh: Region 18-Young Meghna Estuarine Floodplain. J. Fac. Agr., Kyushu Univ., 60: 457-462

AIS 2015 Krishi Diary (In Bengali). Agriculture Information Service, Ministry of Agriculture, Dhaka (Bangladesh), p. 2

BARC 2012 Fertilizer Recommendation Guide. Bangladesh Agricultural Research Council, Farm-Gate, Dhaka (Bangladesh), p. iii, 274

BBS 2013 Statistical Yearbook of Bangladesh. $32^{\text {nd }}$ edition. Bangladesh Bureau of Statistics. Statistics and Information Division (SID), Ministry of Planning, Government of the People's Republic of Bangladesh, Dhaka (Bangladesh), pp. $1-554$

FAO-UNDP 1988 Land Resources Appraisal of Bangladesh for Agricultural Development. Report 2. Agroecological Regions of Bangladesh. FAO, Rome (Italy), p. 570

Islam, M. N., A. Z. M. Moslehuddin, A. K. M. M. Hoque, I. U. Ahmed and K. Egashira 2003 Mineralogy of soils from different Agroecological Regions of Bangladesh: Region 1 - Old Himalayan Piedmont Plain. Clay Sci., 12: 131-137

Moslehuddin, A. Z. M., M. S. Hussain, S. M. Saheed, and K. Egashira 1999 Clay mineral distribution in correspondence with agroecological regions of Bangladesh soils. Clay Sci., 11: 83-94

Moslehuddin, A. Z. M., and K. Egashira 1996 Mineralogical composition of some important paddy soils of Bangladesh. Bull. Inst. Trop. Agr., Kyushu Univ., 19: 33-54

Saheed S. M. 1984 Soils of Bangladesh. In "Proceedings of the International Symposium on Soil Test Crop Response Correlation Studies" ed. by M. A. Mannan, A. K. M. Habibullah and S. Portch, Bangladesh Agricultural Research Council and Soil Science Society of Bangladesh, Dhaka (Bangladesh), pp. $107-129$

Schulze, D. G. 1989 An introduction to mineralogy. In: "Minerals in Soil Environments", ed. by J. B. Dixon and S. B. Weed, Soil Science Society of America, Madison, WI (USA), pp. 1-34

SRDI 1999 Land and Soil Resources Utilization Guide, Chatkhil Upazila, Noakhali (in Bengali). Upazila Nirdeshika series. Vol. 306, Soil Resource Development Institute, Dhaka (Bangladesh), p. 33

SRDI 2000 Land and Soil Resources Utilization Guide, Burichong Upazila, Comilla (in Bengali). Upazila Nirdeshika series. Vol. 333, Soil Resource Development Institute, Dhaka (Bangladesh), pp. 34-35

SRDI 2001 Land and Soil Resources Utilization Guide, Teknaf Upazila, Cox's Bazar (in Bengali). Upazila Nirdeshika series. Vol. 371, Soil Resource Development Institute, Dhaka (Bangladesh), pp. 54-57 